\title{
$\mathrm{Er}$ :YAG レーザによる歯質の除去特性* (注水による気泡の発現と効果)
}

\section{Removal Characteristics of Dental Tissue with Er:YAG Laser Irradiation (Effect of Laser Induced Bubble on Cavity Preparation)} \\ Tatsuaki FURUMOTO ${ }^{* 1}$, Kaoru NAKATANI, Tetsuya HAYASHI, \\ Takashi UEDA, Akira HOSOKAWA and Ryutaro TANAKA \\ ${ }^{* 1}$ Institute of Science and Engineering, Kanazawa Univ. \\ Kakuma-machi, Kanazawa, Ishikawa, 920-1192 Japan
}

古本達明 ${ }^{* 1}$ ，中谷 馨*2，林 鉄也 $^{* 3}$ 上田隆司 ${ }^{* 1}$, 細川 晃 ${ }^{* 1}$, 田中隆太郎 ${ }^{* 4}$

This paper deals with the removal characteristics of dental hard tissues by irradiation of a pulsed Er:YAG laser beam with a wavelength of $2940 \mathrm{~nm}$. The influence of water-layer thickness on the cavity preparation is experimentally investigated. As a specimen, extracted human tooth is used and the laser beam is irradiated to its surface through the optical fiber. Additionally, the phenomenon of the laser beam irradiation in the water environment is observed with a high speed video camera. As a result, the irradiated laser beam in water environment is immediately absorbed to water, and the evaporated area could make it possible to transmit the laser beam without any absorption. The removal volume on human tooth in water environment was increased with increasing the irradiated laser energy, and decreased with increasing the water-layer thickness. There were no thermal damages on the cavity surface in each condition. The eliminated volume in water environment was quite larger than that in air environment. The human tooth in water environment was eliminated by the bubble formation which was caused by laser beam irradiation in addition to the ablation of human tooth which was caused by the absorption of laser beam directly.

Key Words : Laser Processing, Er:YAG Laser, Dental Hard Tissue, Cavity Preparation, Laser Induced Bubble

\section{1. 緒言}

レーザは, 1917 年に発表された誘導放出の理論に端を発し ${ }^{(1)}, 1960$ 年にルビーレーザの発振に成功して以来 ${ }^{(2)}$, $\mathrm{Nd}: \mathrm{YAG}$ レーザ(3), $\mathrm{CO}_{2}$ レーザ(4)，半導体レーザ(5)など様々なレーザが開発されている．歯科医療の分野でレーザ の適用が検討され始めた時期もこれらと重なっており，1964 年から各種基礎研究が開始された ${ }^{(6)}$.その後，レー ザ照射に起因して硬組織の而酸性が得られることが示され(7), 感染歯質を除去するために回転切削器具の代替と して使用するだけでなく，う蝕を予防するという新しい使用法が提案されてきた ${ }^{(8)}$.また，レーザ照射に起因し て発現する鈍麻作用によって無麻酔下で治療することが可能となるなど(9)，これまでに無い新しい術式が適用さ れている.

なかでも，発振波長が $2940 \mathrm{~nm}$ である Er:YAG レーザは，水に対する吸収性に優れるという特長を有し，この 特長を活かした様々な治療に応用されている，一般的に，口腔内で Er:YAG レーザを用いて治療を行うとき，照

* 原稿受付 2012 年 5 月 1 日

${ }^{* 1}$ 正員，金沢大学理工研究域（广920-1192 石川県金沢市角間町）

*2 正員, 金沢大学大学院（現 三菱電機(株)（广467-8530 愛知県名古屋市瑞穂区須田町 2-56)）

*3 学生員, 金沢大学大学院（下920-1192 石川県金沢市角間町）

*4 正員, 広島大学大学院（干739-8527 広島県東広島市鏡山 1-4-1）

E-mail: furumoto@t.kanazawa-u.ac.jp 
射部周辺への熱影響を少なくするため照射部近傍に注水しながらレーザが照射される．これまで，Er:YAG レー ザによる歯質の除去と注水との関連について多くの報告がなされている. Visuri らは(10), 照射部に噴霧した水の 有無による歯質の除去特性について調べ，噴霧した冷却水によって歯質の除去量は大きく減少せず，注水しなが ら照射部近傍を冷却することで照射部近傍の温度上昇を $3^{\circ} \mathrm{C}$ 以下に抑えることが可能であると報告している．ま た, Mir らは ${ }^{(11)}$, 水膜の厚さの違いによる歯質の除去特性について調べ, 水膜を薄くすることで歯質の除去量が 増大したと報告している，その他にも，象牙質表面に Er:YAG レーザを照射してそのときの温度変化を熱電対で 測定し, 回転切削器具で象牙質を切削するときに生じる温度との比較や, 生じる温度に及ぼす注水の効果につい て調べた報告がなされるなど，レーザ照射部に生じる熱の抑制に主眼が置かれた研究が多く行われている(12).

他方, Er:YAG レーザ照射による歯質の除去機構を調べる検討も数多く行われている. Kumazaki らは(13), 歯質 を構成しているエナメル質や象牙質の吸収スペクトルを調べ，歯質が Er:YAG レーザの波長に対して高い吸収性 を有していることを示した. エナメル質の場合, 97\%がハイドロキシアパタイト $\left(\mathrm{Ca}_{10}\left(\mathrm{Po}_{4}\right)_{6}(\mathrm{OH})_{2}\right), 1 \%$ 年有機質, $2 \%$ 䓠で構成されている ${ }^{(14)}$ ，そのため，歯質と水の最大吸収帯が近似しているのはハイドロキシアパタイト内 の OH 基に起因しており, Er:YAG レーザを歯質表面に照射したときの除去機構は, ハイドロキシアパタイト内の $\mathrm{OH}$ 基にレーザが吸収され, そのとき歯質が瞬時に蒸発したことによると結論づけている. また, Meister らは ${ }^{(15)}$, 脱水した歯質に対して Er:YAG レーザを照射し，外部から供給された水およびハイドロキシアパタイト内の水酸 基が歯質の除去特性に及ぼす影響を調べた。その結果，脱水の有無による歯質の除去特性に違いは無く，外部か ら水が供給された時にのみ歯質のアブレージョンが生じたと報告している. その他にも, Kang らは黒色のアクリ 儿樹脂表面の水層厚さと材料除去量との関係を調心(16), Er:YAG レーザの水に対する吸収率が大きいため水層が 厚くなるにつれて材料の除去効率が大きく減少したと報告している．しかしながら，歯質表面への水・空気の混 合噴霧量が除去体積に及ぼす影響を調べた結果，注水することで歯質の除去量が向上したとの報告もされている (17). 寸なわち, Er:YAG レーザ照射時に水が介在することで，材料表面でどのような現象が生じているのか明ら かにされていない点が多いのが現状である(18).

そこで, 本研究では Er:YAG レーザの水に対する吸収特性を調べると共に，水中でレーザ照射したときの様子 を高速度カメラで撮影してレーザ照射時の現象を詳細に考察した. また, 対象材料として抜去したヒトのエナメ ル質を用いて，試料表面の水層の有無による除去特性を調べ，レーザ条件と除去深さや除去体積との関係を明ら かとしたので，以下に報告する。

\section{Er:YAG レーザの特性}

\section{$2 \cdot 1$ Er:YAG レーザ歯科治療器}

本実験に用いたレーザ歯科治療器の仕様を表 1 に示寸. 波長が $2940 \mathrm{~nm}$ のパルス Er:YAG レーザ((株)モリタ製

Table 1 Specification of laser

\begin{tabular}{|c|c|c|}
\hline Laser beam & & Er:YAG (PW) \\
\hline Wavelength [ $\mathrm{nm}$ ] & $\lambda$ & 2940 \\
\hline Energy [ $\mathrm{mJ} /$ pulse ] & $E$ & $23-191$ \\
\hline Pulse width $[\mu \mathrm{s}]$ & $\tau$ & 200 \\
\hline Frequency $[\mathrm{Hz}]$ & $f$ & $1-25$ \\
\hline \multicolumn{3}{|l|}{ Contact tip } \\
\hline $\begin{array}{l}\text { Material } \\
\text { Diameter }[\mu \mathrm{m}]\end{array}$ & $f_{\mathrm{c}}$ & $\begin{array}{l}\text { Quartz } \\
600\end{array}$ \\
\hline
\end{tabular}

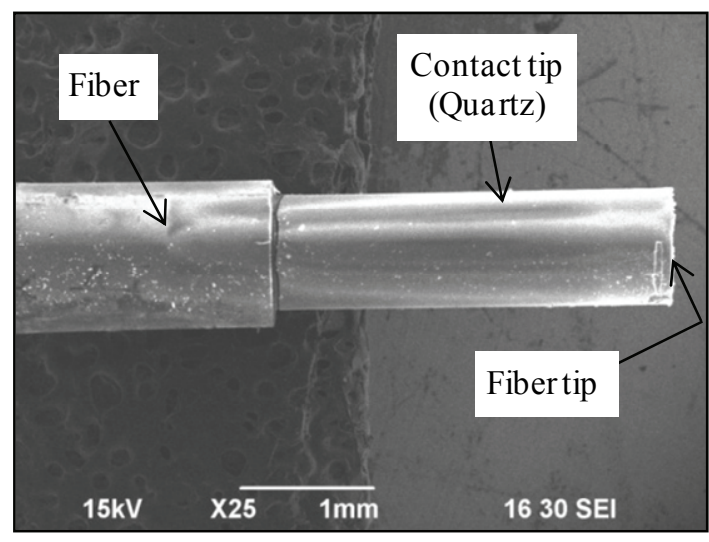

$500 \mu \mathrm{m}$

Fig. 1 SEM image of fiber tip 


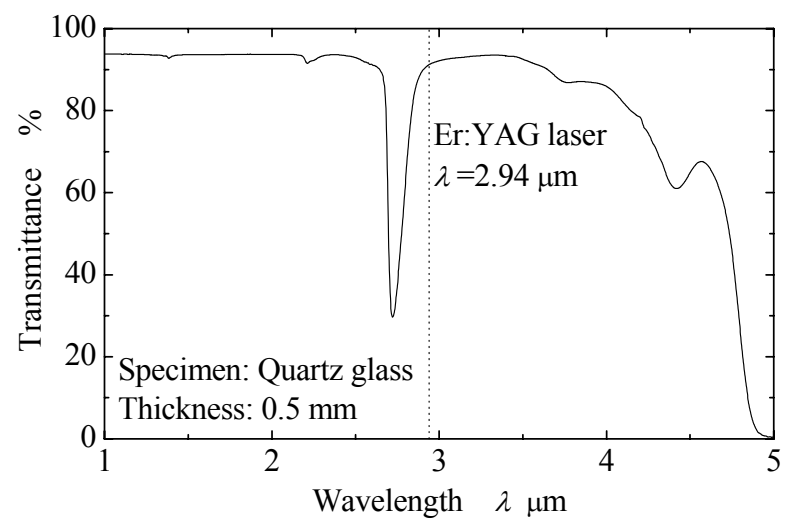

Fig. 2 Transmittance of quartz glass

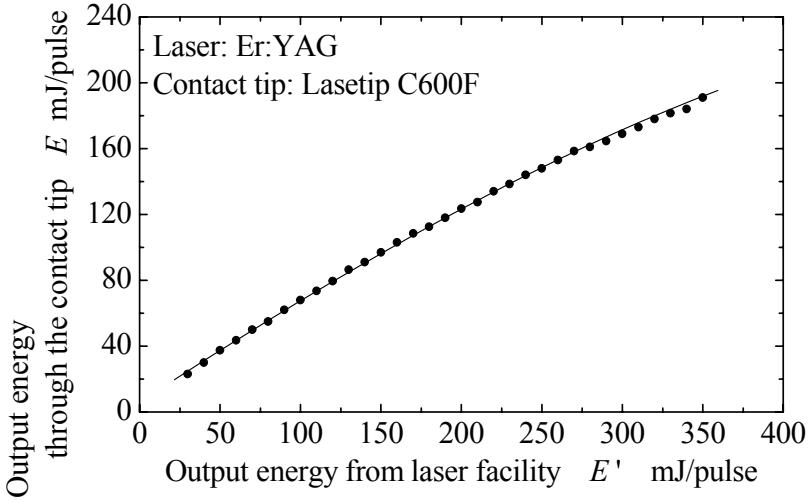

Fig. 3 Emission energy from contact tip

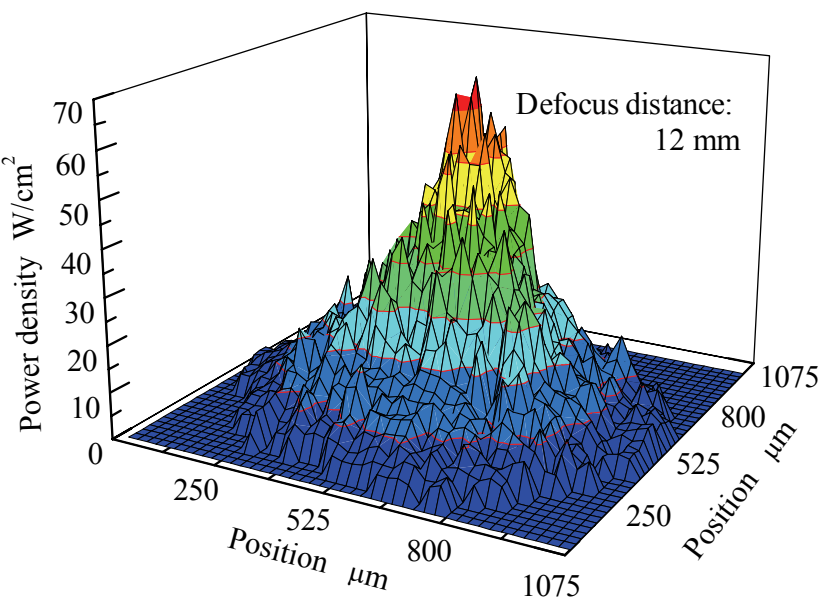

Fig. 4 Beam profile emitted from contact tip

作所製: Erwin AdvErL)である. 発振されたレーザ光は中空ファイバによって伝送され，図 1 に示すようにファイ バ先端に取り付けられたコンタクトチップを介して出射される. コンタクトチップは石英ガラスで製作されてお り，治療時に患部への接触端子として使用される．実験に使用したコンタクトチップ((株)モリタ製作所：レザチ ップ (600F)は，先端がフラット状でありその直径は $600 \mu \mathrm{m}$ である.

図 2 は，近赤外分光光度計((株)パーキンエルマージャパン製: Spectrum One NTS)を用いて，試料厚さが $0.5 \mathrm{~mm}$ である石英ガラスの分光透過特性を調べた結果である. グラフから, Er:YAG レーザの発振波長である $\lambda=2.94 \mu \mathrm{m}$ のとき透過率が $T=91 \%$ であった. この值を用いて, ランベルトベールの法則による材料の吸収係数 $\beta$ を求めたと ころ $\beta=0.19 \mathrm{~mm}^{-1}$ となった ${ }^{(19)}$. すなわち, 本実験で用いるレーザ歯科治療器のファイバ光学系先端に取り付けら れたコンタクトチップから，減衰したレーザが出射されることとなる，そこで，中空ファイバ先端から出射され るレーザエネルギをパワーメータ(Ophir 製:F150A)で測定し，コンタクトチップの有無に起因したレーザ光の減衰 特性を調べた。 図 3 に，発振エネルギとコンタクトチップ先端からの出射エネルギとの関係を示す．発振エネル ギとコンタクトチップ先端からの出射エネルギに相関が認められ，コンタクトチップを介することで先端からの 出力が $60 \%$ 程度になることがわかった．この結果から，本論文で扱うレーザエネルギは，照射条件ごとに測定し たコンタクトチップ先端から出射されるエネルギとした.

\section{$2 \cdot 2$ レーザの出力分布}

コンタクトチップ先端から出射されるレーザの分布を調べるため, 光電変換素子を用いてプロファイル測定を 行った. 実験に用いた素子は, Er:YAG レーザの波長を受光可能な PbSe 素子(浜松ホトニクス(株)製: P791-02)であ 
Table 2 Experimental conditions for observation of laser irradiation in water environment

\begin{tabular}{|c|c|c|}
\hline \multicolumn{3}{|l|}{ High speed camera } \\
\hline Recording speed [ fps ] & & 100,000 \\
\hline Sampling time $[\mu \mathrm{s}]$ & & 10 \\
\hline Resolution [ - ] & & $320 \times 192$ \\
\hline \multicolumn{3}{|l|}{ Light source } \\
\hline \multicolumn{3}{|l|}{ Observation cell } \\
\hline $\begin{array}{l}\text { Material } \\
\text { Size }[\mathrm{mm}]\end{array}$ & & $\begin{array}{l}\text { Quartz } \\
3 \times 10 \times 44\end{array}$ \\
\hline Environment & & Distilled water \\
\hline \multicolumn{3}{|l|}{ Laser conditions } \\
\hline Energy [ mJ/pulse ] & $E$ & 102 \\
\hline Pulse width $\lceil\mu \mathrm{s}\rceil$ & $\tau$ & 200 \\
\hline Number of pulse [ number ] & $n$ & 1 \\
\hline
\end{tabular}

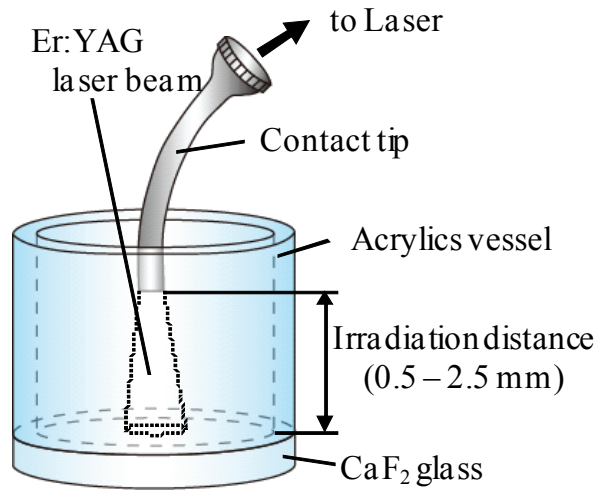

Fig. 5 Experimental conditions

る. 素子の受光面上に直径が $25 \mu \mathrm{m}$ のピンホール(シグマ光機(株)製: PA-25HEL)を設置し，ピンホールを通過した レーザを素子で受光して, 得られた電気信号をオシロスコープで記録した. そして，レーザ照射領域内でこの素 子を $25 \mu \mathrm{m}$ 間隔で 2 次元走查し，各位置で得られた出力と別途測定したレーザエネルギの值から，コンタクトチ ップ先端から出射されるレーザのプロファイルを求めた．測定は，ピンホールや素子の損傷を防ぐためコンタク トチップ先端から $12 \mathrm{~mm}$ の位置で行った.

チップ先端から $12 \mathrm{~mm}$ の位置でのレーザプロファイルを図 4 に示寸. 図から, コンタクトチップから出射され るレーザは中心付近の出力が大きく, 中心から離れるにつれて出力が弱くなるガウス状の分布を呈していること がわかる. ピーク出力に対して $1 / \mathrm{e}^{2}$ の強度を有する位置でのビーム径は $760 \mu \mathrm{m}$ であった. 今後, コンタクトチ ップ先端からの距離に対するビーム径を取り扱うが，これらの值は同様の実験をコンタクトチップ先端から 16 $\mathrm{mm}$ の位置について行い, 得られた $2 つ の$ 結果から相似的に算出した值を用いている.

\section{Er:YAG レーザの水中照射による歯質除去特性}

\section{$3 \cdot 1 \quad$ Er:YAG レーザの水中照射時の高速度カメラ観察}

水中でコンタクトチップ先端から Er:YAG レーザを出射したときの様子について, 高速度ビデオカメラ((株)> オトロン製: FASTCAM SA5 model 1300K C2 )を用いて撮影した. 実験条件を表 2 に示す. 使用した高速度ビデオ カメラのサンプリング間隔は $10 \mu \mathrm{s}$ であり，解像度は $320 \times 192$ である. 光源にはメタルハライドランプ((株)フォ トロン製: HVC-UL)を用いた. まず，内径が $3 \times 10 \times 44 \mathrm{~mm}$ の石英セルの中に蒸留水を満たし，その中にコンタク トチップを挿入した. そして, コンタクトチップの先端が石英セルの底面から $30 \mathrm{~mm}$ の位置となるように調整し， 表 2 に示寸条件でレーザ照射を行ってその時の様子を観察した．また，石英セルとコンタクトチップ先端との距 離が $1 \mathrm{~mm}$ の条件でレーザ照射を行い, レーザ照射に起因して生じる気化領域の挙動についても観察を行って比 較した.

\section{$3 \cdot 2$ 水に対する Er:YAG レーザの吸収特性}

Er:YAG レーザの水に対する吸收係数は $\beta=10^{5} \mathrm{~mm}^{-1}$ であることが知られ ${ }^{(20)}$ ，照射したレーザ光は殆ど全てが極 表面で吸収され気化することがわかっている，そこで，水中で Er:YAG レーザを照射したとき，レーザ照射に起 因して生じる気化領域がレーザ透過特性に与える影響を調べるため, 水膜厚さの異なる条件でレーザ照射を行い, そのとき気化領域内を透過するレーザエネルギをパワーメータで測定した．実験装置概略を図 5 に示す. 蒸留水 を満たす容器は, 底面に Er:YAG レーザの波長を $90 \%$ 程度透過する厚さ $1 \mathrm{~mm}$ の $\mathrm{CaF}_{2}$ ガラスを使用し, 側面はア クリル樹脂を用いて製作した. コンタクトチップ先端と $\mathrm{CaF}_{2}$ ガラス面との距離を $0.5-2.5 \mathrm{~mm}$ の範囲で変化させ 

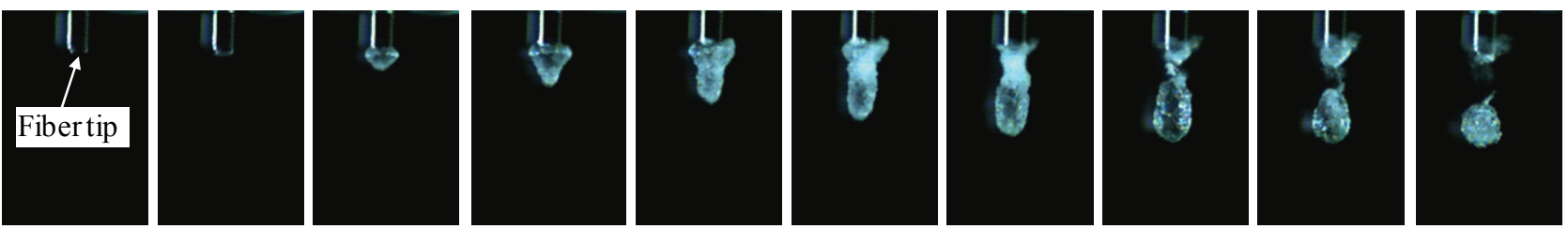

$1 \overline{\mathrm{mm}}$

(a) Before

(b) $10 \mu \mathrm{s}$

(c) $40 \mu \mathrm{s}$

(d) $80 \mu \mathrm{s}$

(e) $120 \mu \mathrm{s}$

(f) $160 \mu \mathrm{s}$

(g) $200 \mu \mathrm{s}$

(h) $240 \mu \mathrm{s}$

(i) $280 \mu \mathrm{s}$

(j) $320 \mu \mathrm{s}$
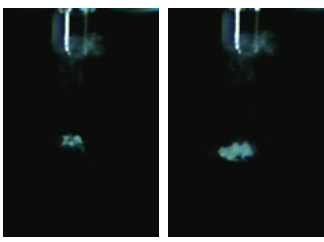
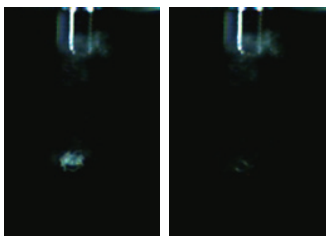
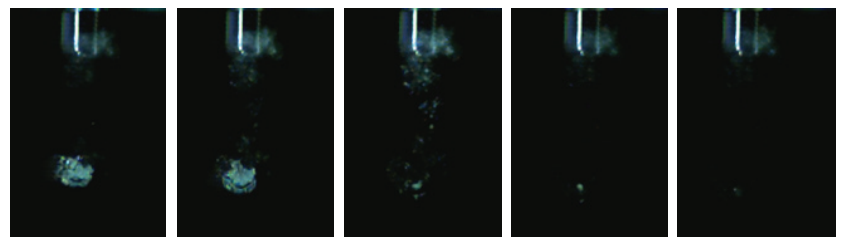

$1 \overline{\mathrm{mm}}$

(k) $360 \mu \mathrm{s}$

(1) $400 \mu \mathrm{s}$

(m) $440 \mu \mathrm{s} \quad$ (n) $480 \mu \mathrm{s}$

(o) $520 \mu \mathrm{s}$

(p) $560 \mu \mathrm{s}$

(q) $600 \mu \mathrm{s}$

(r) $640 \mu \mathrm{s}$

(s) $680 \mu \mathrm{s}$

(t) $720 \mu \mathrm{s}$

Fig. 6 Observation of fiber tip during laser beam irradiation in water environment

ながら，レーザ照射時に $\mathrm{CaF}_{2}$ ガラスを透過してきたレーザをパワーメータで測定した. また, 容器内に蒝留水を 満たしてレーザ照射したときの透過エネルギの測定も行って, 蒸留水の有無による透過エネルギの違いを比較し た.

\section{$3 \cdot 3 \quad$ Er:YAG レーザによる歯質の除去特性}

歯質表面の水膜の有無が歯質の除去特性に及ぼす影響を調べるため，歯質表面にレーザ照射したときに生じる 窩洞の体積や深さを測定して評価した。用いた試料は，抜去後に生理食塩水中で保存されたヒトの臼歯であり， ヘルシンキ宣言を遵守し，その主旨にしたがって倫理的に実験が行われた．レーザ照射位置は歯冠部エナメル質 の健全歯面であり，照射部を\#150 の研磨紙で平滑化して用いた．実験は，レーザエネルギやコンタクトチップと 照射歯面との距離を変えながら気中下と水中下とで行い，水の有無による除去特性の違いを比較した。レーザ照 射後，得られた窩洞は 3 次元表面粗さ計((株)東京精密製：サーフコム 2000DX-3DF)で形状測定を行い，除去体積 および除去深さを評価すると共に，レーザ照射部を電子顕微鏡で観察した.

\section{4. 実験結果および考察}

\section{$4 \cdot 1$ レーザ照射部の高速度カメラ観察}

レーザエネルギが $102 \mathrm{~mJ} / \mathrm{pulse}$ のとき，蒸留水中でコンタクトチップ先端からレーザを単発照射したときの先 端付近の様子について，高速度ビデオカメラで撮影した結果を図 6 に示寸．Er:YAG レーザは，前述したように 水に対する吸收係数が $\beta=10^{5} \mathrm{~mm}^{-1}$ であるため, コンタクトチップ先端では図 6(b)に示すようにレーザ照射直後か ら水の気化に伴って発生する蒸気泡が観察された，その後，蒸気泡は図 6(d)に示すように前述したレーザプロフ アイルの形状に沿うように大きくなり，レーザのパルス幅である $200 \mu \mathrm{s}$ までレーザ照射方向に対して円柱状に成 長した. また, レーザが照射されている間は, 蒸気泡の位置が時間の経過と共にファイバ先端から離れていった. これらのことより，レーザ照射によって生じた蒸気泡の内部ではレーザの吸収がほとんど行われていないことが わかる．レーザ照射によって蔒気泡が生じると，それに伴ってレーザが吸収される位置がレーザ照射方向に対し て前方に移動し，その位置でレーザを吸収して蒸気泡が形成されることを繰り返すため，次第にファイバ先端か ら離れた位置で蒸気泡が生じたと考えられる.

レーザ照射が終了すると，図 6(h)に示すようにコンタクトチップ先端付近から蒸気泡が消失して次第に球状と なり，図 6(o)に示寸照射開始から $520 \mu \mathrm{s}$ までの間はその領域が小さくなっていった。これは，周辺に存在する水 


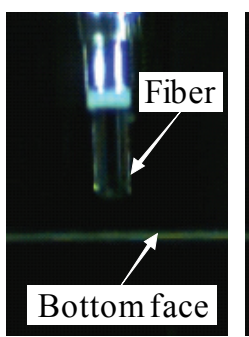

(a) Before

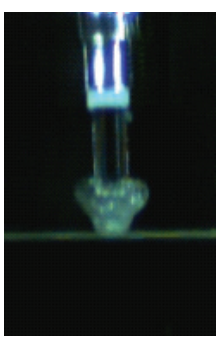

(b) $80 \mu \mathrm{s}$

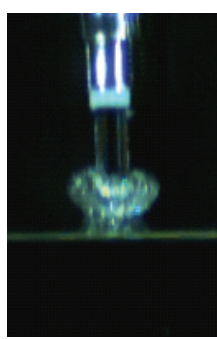

(c) $160 \mu \mathrm{s}$

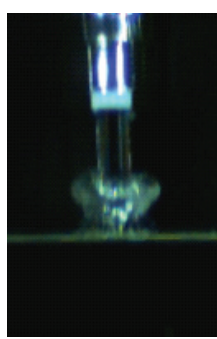

(d) $240 \mu \mathrm{s}$

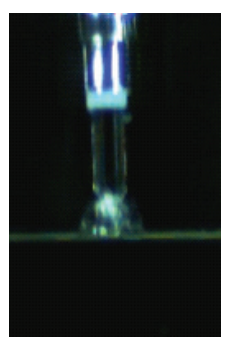

(e) $320 \mu \mathrm{s}$

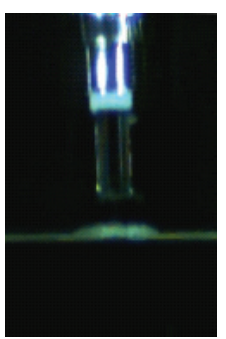

$\overline{1 \mathrm{~mm}}$

Fig.7 Influence of distance from fiber tip to bottom face on evaporation of distilled water

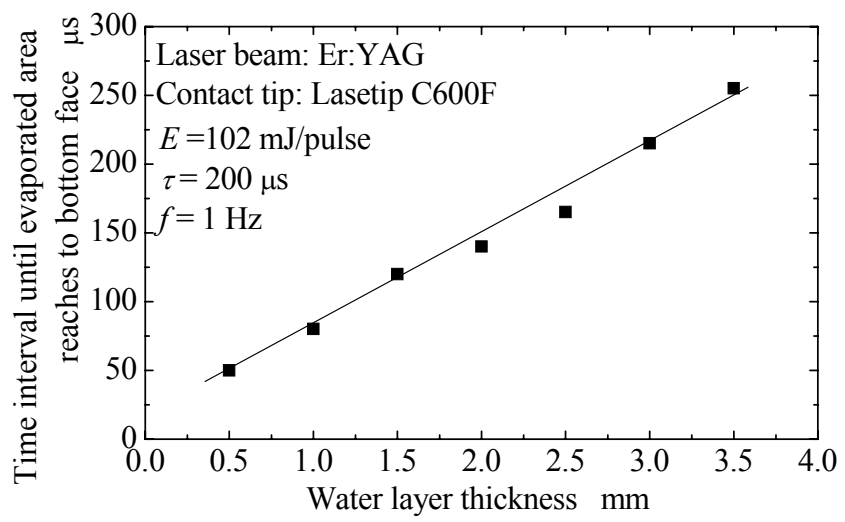

Fig.8 Influence of water layer thickness on the reached time of the vapor bubble

から受ける圧力との作用に起因していると考えられるレレザ照射が終了してエネルギ供給がなくなると，蒸気 泡は周辺の水からの圧力を受けて球状となり，気化領域の一部は周辺の水による冷却作用によって液化しながら 次第に小さくなっていったと考えられる. その後，図 6(p)に示すように照射開始から $560 \mu \mathrm{s}$ 経過した時に再び気 化した領域が形成され，時間の経過と共にその領域が小さくなり，照射開始から $720 \mu \mathrm{s}$ 経過すると図 6(t)に示す ように気化した領域が完全に消失した。これらの変化は，蒸気泡の急激な収縮に伴ってキャビテーションが発生 し消失した結果であると考えられる．医療の現場では，Ho:YAG レーザなどを照射したときに生じるキャビテー ションを臨床にも適用しており ${ }^{(21)}$, Er:YAG レーザを水中で照射したときにも同様のキャビテーションが生じた と考えられる.

図 7 は, レーザエネルギが $102 \mathrm{~mJ} / \mathrm{pulse}$, ファイバ先端と石英セル底面との距離が $1 \mathrm{~mm}$ の条件でレーザ照射を 行い，そのときの様子を高速度ビデオカメラで観察を行った結果である．レーザ照射直後に生じた蒸気泡は，図 7(b)に示寸ように照射開始から $80 \mu \mathrm{s}$ 経過したときに底面に接触し, その後, 蒸気泡は底面上を横に広がっていっ た．また，図 7(d)に示すようにレーザパルス幅である照射開始から $200 \mu \mathrm{s}$ を超えてもファイバ先端と底面との間 に蒸気泡が存在し，時間の経過と共に次第に消失していったここれの結果より，レーザパルス幅より短い時間 で蒸気泡がセル底面に到達しており, 到達後はファイバ先端と底面との間に水が介在しない状態となることがわ かった．そのため，蒸気泡がセル底面に到達してからパルスレーザ照射が終了するまでの時間は，気中でレーザ 照射したときと同じ状態となり, 水中照射の条件でも Er:YAG レーザが深部まで到達すると考えられる. そこで, 同一のレーザ照射条件を用いてファイバ先端と石英セル底面との距離を変えながらレーザ照射を行い, 蒸気泡が セル底面に到達するまでの時間を調べた結果を図 8 に示す．蒸気泡が底面に到達するまでの時間は，ファイバ先 端からの距離が長くなるにつれて線形的に長くなった。 レーザ照射エネルギが $102 \mathrm{~mJ} / \mathrm{pulse}$ の条件では，ファイ バ先端からの距離が $2.7 \mathrm{~mm}$ の時, 到達時間がレーザパルス幅である $200 \mu \mathrm{s}$ となった. 寸なわち, ファイバ先端 


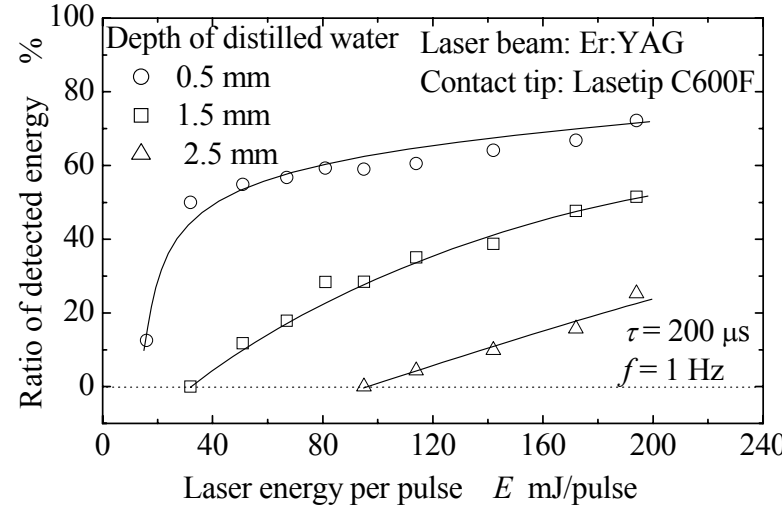

Fig. 9 Variation of transmittance with irradiated energy

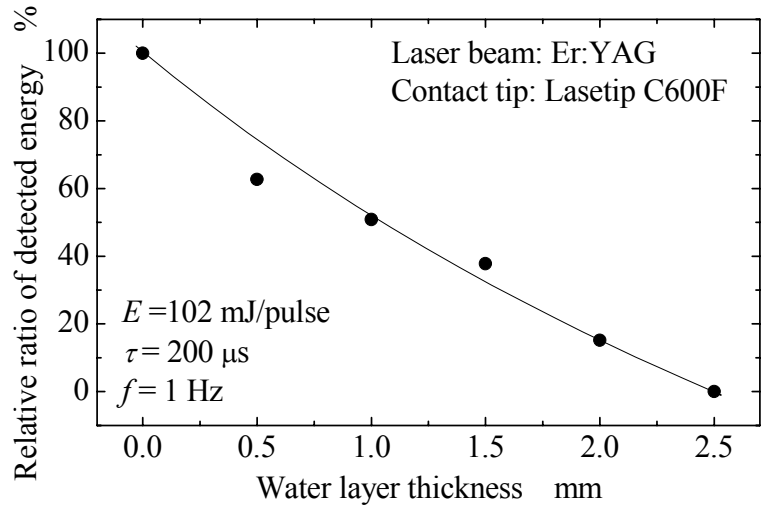

Fig.10 Variation of transmittance with water layer thickness

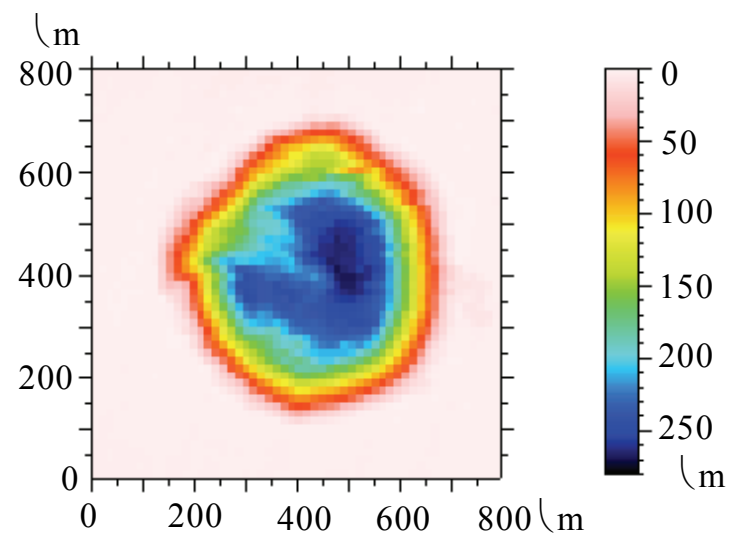

Fig. 11 Profile of prepared cavity

(E: $104 \mathrm{~mJ} /$ pulse, Distance from fiber tip to specimen: $0.5 \mathrm{~mm}$, Environment: In water)

からの距離が $2.7 \mathrm{~mm}$ を超えると, 照射したレーザは底面に到達する前にほとんど全てのエネルギが水に吸収され ると考えられる.

\section{$4 \cdot 2$ 水膜厚さがレーザ透過特性に及ぼす影響}

図 9 は，水膜の厚さがそれぞれ $0.5 \mathrm{~mm} ， 1.5 \mathrm{~mm} ， 2.5 \mathrm{~mm}$ であるとき，エネルギを変えながらレーザを単発照 射したときに得られた測定值から透過率を求めた結果である。前節で述べたように，レーザ照射することでファ イバ先端に蒸気泡が生じることから，水中でレーザ照射を行ってもレーザエネルギが検出された．そのエネルギ は, いずれの水膜厚さの条件でもエネルギの上昇と共に増加した. また, 水膜厚さが $1.0 \mathrm{~mm}$ のき $32 \mathrm{~mJ} / \mathrm{pulse}$, 水膜厚さが $1.5 \mathrm{~mm}$ のとき $95 \mathrm{~mJ} / \mathrm{pulse}$ 以下の条件ではエネルギが検出されなかった．そこで，レーザエネルギが $102 \mathrm{~mJ} / \mathrm{pulse}$ のとき，水膜厚さがレーザ透過特性に及ぼす影響を調べた結果が図 10 である. 水が介在しない条件 でレーザ照射を行い, そのとき $\mathrm{CaF}_{2}$ ガラスを透過してきたエネルギを $100 \%$ として相対的にまとめた結果である. 水膜の厚さが $0.5 \mathrm{~mm}$ の時 $63 \%$ であったエネルギ透過率は, 水膜が厚くなるにつれて次第に小さくなり, 水膜の厚 さが $2.5 \mathrm{~mm}$ を超えると透過率が $0 \%$ となった。この值は，図 8 で示した蒸気泡が底面に到達するまでの時間とほ ぼ一致した．これらの結果から，パルスレーザが照射されている $200 \mu \mathrm{s}$ の時間の中で，照射開始直後はレーザが ファイバ先端付近の水に吸収され，照射されたエネルギが蒸気泡を形成させるために使用されたが，蒸気泡が形 成された後はレーザが蒸気泡の内部を透過したと考えられる.

\section{$4 \cdot 3$ レーザェネルギが歯質の除去特性に及ぼす影響}

レーザ照射で得られた窩洞について，3 次元表面粗さ計で測定して得られたプロファイル例を図 11 に示寸.フ 


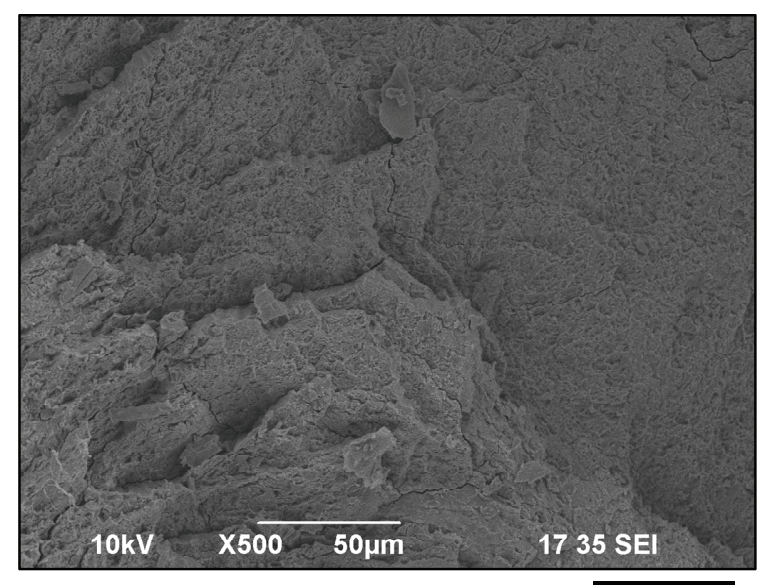

$50 \mu \mathrm{m}$

Fig. 12 SEM image at the irradiated surface of the prepared cavity

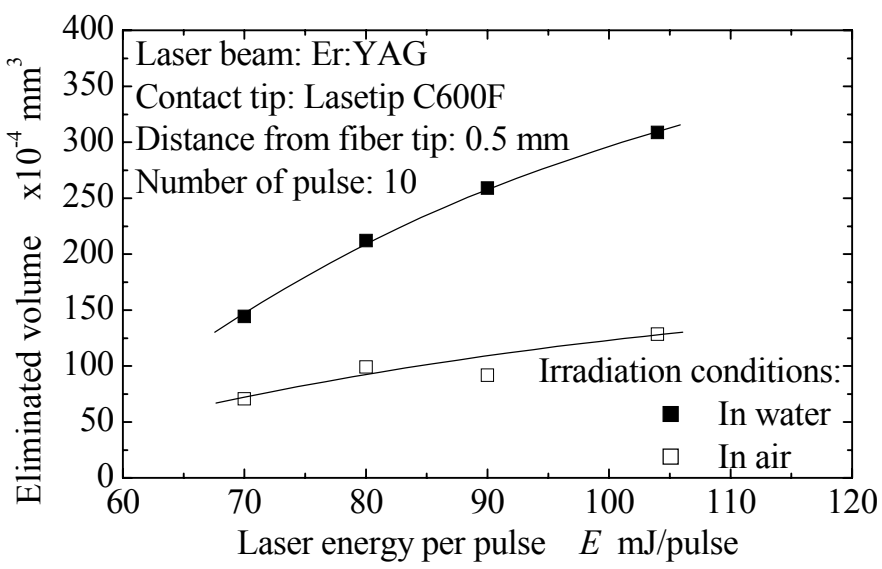

Fig. 13 Influence of laser energy on removal volume

アイバ先端と歯質表面との距離が $0.5 \mathrm{~mm}$ ，エネルギが $104 \mathrm{~mJ} / \mathrm{pulse}$ の条件で，レーザを水中照射して得られた結 果である. コンタクトチップ先端から出射されるレーザは, 図 4 で示したように中心付近の出力が大きく, 中心 から離れるにつれて出力が弱くなるガウス状の分布を呈していた．レーザ照射で得られた窩洞についても同様の 傾向を示し,レーザ出力分布に沿うように中心付近が最も深くエッジに近接するにつれて浅くなる形状となった. 図 12 は得られた窩洞の中心付近を電子顕微鏡で観察した結果である. 図に示寸ように, 照射部表面ではレーザ照 射に起因した熱変質層が観察されず，表面がむしり取られたような形状となった。この結果は，気中下でレーザ 照射して得られた窩洞も同様であった。したがって，水膜の有無が Er:YAG レーザ照射で得られた窩洞に及ぼす 形態学的な違いはほとんど無いと考えられる.

ファイバ先端と歯質表面との距離を $0.5 \mathrm{~mm}$ で一定とし, エネルギを変えながら水中でレーザ照射したときに 得られた窩洞の除去体積を測定した結果を図 13 に示す。同一箇所に単発レーザを 10 回照射して得られた窩洞を 評価しているが，レーザ照射前にファイバ先端と歯質表面との間に水が介在していることを確認している．比較 のため，気中でも同様のレーザ照射を行って除去体積を評価した，図に示すように，窩洞の除去体積はいずれの 条件でもレーザエネルギが大きくなるにつれて増加した，一方，水中照射と気中照射と比較するとファイバから 出射されるレーザエネルギが同じ場合，いずれの条件でも水中照射の方が除去体積は大きくなり，エネルギが大 きくなるにつれて水中条件と気中条件の除去体積の違いが大きくなった．また，ファイバから出射されるエネル ギが $104 \mathrm{~mJ} / \mathrm{pulse}$ のとき, 水中照射ではエネルギの一部がファイバ先端付近に気化領域を形成するために使用さ れ，歯面に到達して窩洞形成に用いられる実質エネルギは $60 \mathrm{~mJ} / \mathrm{pulse}$ となるにも関わらず，ほとんど全てエネル 


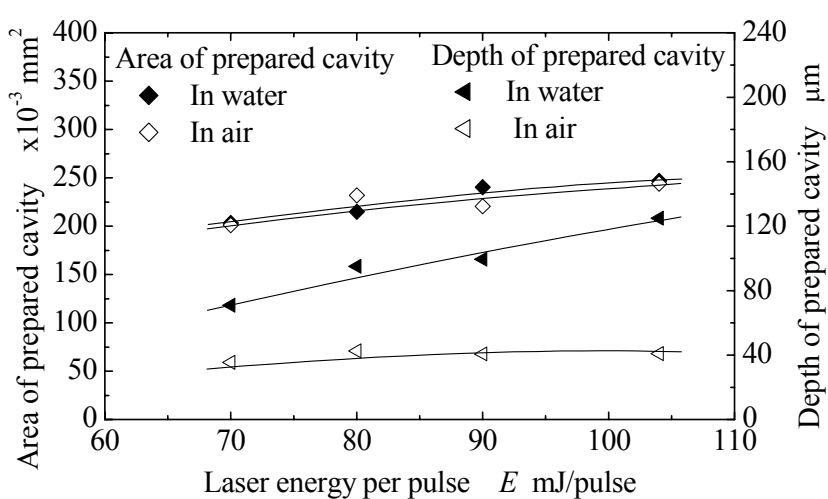

Fig. 14 Influence of laser energy on cavity area and depth

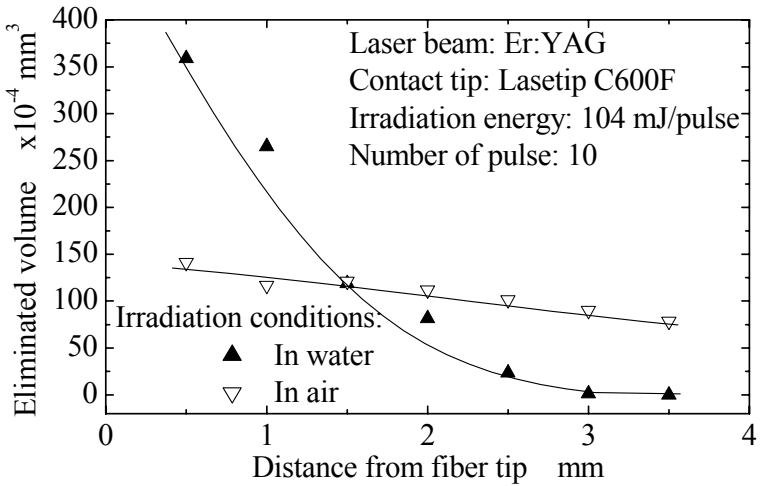

Fig. 15 Variation of eliminated volume with irradiation distance

ギが窩洞形成に使用される気中実駼結果と比較して，除去体積が 2.4 倍も大きかった.

この結果より，歯質表面に存在する水膜が窩洞形成に大きく寄与していることが示唆される．筆者らのこれま での研究で, 波長が $1064 \mathrm{~nm}$ である Nd:YAG レーザを歯質に照射すると, 生じた熱で歯質が溶融・蒸散して照射 部表面に再凝固層が形成されるのに対して，気中下で Er:YAG レーザを歯質に照射したときの表面温度は，歯質 の主成分であるハイドロキシアパタイトの融点よりも著しく低いことが示されている(22). したがって，気中下で Er:YAG レーザを照射して得られた窩洞は，レーザ照射で生じた熱に起因して得られたとは考えにくく，歯質内 に含まれる $\mathrm{OH}$ 基にレーザが吸収され，歯質が瞬時に蒸発することで除去されるメカニズムが主要因であると考 えられる，一方，水中下でレーザ照射したときに得られた窩洞は，レーザ照射直後から発生する蒸気泡やレー ザ照射後に蒸気泡が急激に収縮することで発生するキャビテーションが寄与していると考えられる.ファイ バ先端から出射されたレーザは一部が歯質表面まで到達するため，歯質内に含まれる $\mathrm{OH}$ 基にレーザが吸収され たことに起因する歯質の除去も生じるが，歯質表面への到達エネルギが小さいにも関わらず除去体積が大きいこ とから，水中照射時の窩洞形成は蒸気泡やキャビテーションの影響が大きいといえる．レーザパルス幅が $200 \mu \mathrm{s}$ で照射エネルギが $102 \mathrm{~mJ} / \mathrm{pulse}$ の条件では，前述したように気化領域の形成から消失までの時間間隔は $720 \mu \mathrm{s}$ で ある. 歯質表面近傍ではこの短時間で蒸気泡の生成・消失および二次的なキャビテーションの生成・消失が生じ, それらが歯質の除去に寄与したと考えられる。

図 14 は，ファイバ先端と歯質表面との距離を $0.5 \mathrm{~mm}$ で一定としたとき，形成された窩洞の面積と深さを測定 した結果である．照射エネルギが同じとき，水中と気中の条件下で形成された窩洞の面積に大きな違いは見られ ないが，水中下でレーザ照射したときはエネルギの増加と共に窩洞が深くなった．水中でレーザ照射したときに 生じる蒸気泡やキャビテーションによって歯質の除去が深さ方向に進行したためと考えられ，照射エネルギを大 きくすることで蒸気泡やキャビテーションに起因した歯質を除去するためのエネルギが増大したことを示唆する 結果といえる.

\section{$4 \cdot 4$ 水膜厚さが歯質の除去特性に及ぼす影響}

出射されるレーザエネルギが $104 \mathrm{~mJ} / \mathrm{pulse}$ のとき，ファイバ先端から歯質表面までの距離が除去体積に及ぼす 影響を調べた結果を図 15 に示寸. 水中下と気中下で実験を行った結果である. 図に示寸ように, 気中下でレーザ 照射を行ったとき, ファイバ先端から歯質表面までの距離が長くなるにつれて除去体積が減少した．前述したレ ーザのプロファイル測定結果を用いて歯質表面でのビーム径を算出寸ると, ファイバ先端からの距離が $0.5 \mathrm{~mm} の$ とき $530 \mu \mathrm{m}$ となり, ファイバ先端からの距離が $3.5 \mathrm{~mm}$ のとき $580 \mu \mathrm{m}$ となり, 最大でビーム径が $10 \%$ 程度大き くなった．照射距離による除去体積の違いはこのビーム径に起因しており，ビーム径が大きくなるにつれてエネ ルギ密度が減少し，ハイドロキシアパタイト内の $\mathrm{OH}$ 基にレーザが吸収され歯質が瞬時に蒸発した領域が減 少したためと考えられる.

一方，水中でレーザ照射したとき，ファイバ先端からの距離が長くなるにつれて除去体積が減少する傾向は同 
様であるが，気中照射の結果と比較してその変化が大きかった．また，ファイバ先端からの距離が $1.5 \mathrm{~mm}$ まで は水中照射で得られた窩洞の体積が大きかったが, $1.5 \mathrm{~mm}$ を超えると気中照射で得られた窩洞の体積が大きくな った.これもやはり，歯質内部の $\mathrm{OH}$ 基にレーザが吸収されたことによる要因と，水中でレーザ照射したときに 生じる蒸気泡やキャビテーションによる要因に寄与していると考えられる.ファイバ先端からの距離が短いとき, 歯質表面に到達するエネルギは相対的に大きくなるため, 歯質内部の $\mathrm{OH}$ 基にレーザが吸収されることで瞬時に 蒸発した要因が大きくなる. ファイバ先端からの距離が長くなると, 歯質表面に到達するエネルギが小さくなる ことにともない $\mathrm{OH}$ 基への吸収も少なくなるが，距離が長くなるにつれて蒸気泡やキャビテーションによる気泡 が歯質表面に作用する割合が少なくなったためと考えられる. 図 6 で示した高速度ビデオカメラで撮影した結果 で，蒸気泡やキャビテーションによって生じた気泡が時間の経過と共に小さくなっている様子からもわかる. 水 中でレーザ照射したときに得られた除去体積が，ファイバ先端からの距離に大きく影響していることから，レー ザ照射によって形成された窩洞は，歯質内部の $\mathrm{OH}$ 基ヘレーザが吸収される要因よりもむしろ，蒸気泡やキャビ テーションによって生じた気泡が歯質表面に衝突したことによる要因が主体的であるといえる.

\section{5. 結}

本研究では, Er:YAG レーザの水に対する吸収特性を調べると共に，水中でレーザ照射したときの様子を高速 度カメラで撮影した．また，歯質表面にレーザ照射したとき，表面の水層が歯質の除去特性に及ぼす影響を調べ た. 得られた結果を以下に要約する.

(1) 水中下で Er:YAG レーザを照射すると, 照射直後から水の気化に伴って発生する蒸気泡が生じ，パルスレー ザの照射中は蒸気泡が照射方向に成長する. 照射終了後は, 気化領域が球状になりながら次第に消失し，照射 部近傍の急激な圧変化に起因してキャビテーションによる気泡が発生する.

(2) 水中でレーザ照射すると，照射開始直後はレーザがファイバ先端付近の水に吸収され，照射エネルギが蒝気 泡を形成するために使用される. 蒸気泡の形成後は, その内部でほとんどレーザが吸収されず水中照射の条件 でもレーザが深部まで到達する。

（3）レーザ照射による歯質表面の窩洞形成では，水膜の有無によって歯質除去メカニズムが異なる．水膜が無い 条件では, 歯質内に含まれる $\mathrm{OH}$ 基にレーザが吸収され歯質が瞬時に蒸発することで除去されるメカニズムが 主要因である. これに対して, 水膜を付加するとレーザ照射直後から発生する蒝気泡やレーザ照射後に蒸気 泡が急激に収縮することで発生するキャビテーションが寄与していることが示唆された.

\section{謝 辞}

実験で使用した Er:YAG レーザは株式会社モリタ製作所からお借りした．記して深甚なる謝意を表す．また， 歯科材料の取扱について適切なアドバイスを頂いた杉原歯科クリニック院長 杉原成良氏，旭川歯科クリニック 院長 和賀正明氏に感謝する. 本研究の一部は，科学研究費補助金若手研究(B) 「レーザ光と酸化チタン粉末の 併用による殺菌効果発現のメカニズム解明に関する研究」(課題番号: 21791847)による助成を受けて遂行された.

\section{文献}

(1) Einstein A., "Zur Quantentheorie der Strahlung”, Physika Zeitschrift, Vol. 18 (1917), pp.121-128.

(2) Maiman, T.H., "Stimulated Optical Radiation in Ruby", Nature, Vol. 187 (1960), pp. 493-494.

(3) Kushida, T. and Geusic, J.E., "Optical Refrigeration in Nd-Doped Yttrium Aluminium Garnet", Physical Review Letters, Vol. 21 (1968), pp. 1172-1175.

(4) Patel, C.K.N., "Continuous-Wave Laser Action on Vibrational-Rotational Transitions of $\mathrm{CO}_{2}$ ", Physical Review, Vol. 136 (1964), pp. A1187-1193.

(5) Hall, R.N., Fenner, G.E., Kingsley, J.D., Soltys, T.J. and Carlson, R.D., "Coherent Light Emission from GaAs Junctions", Physical Review Letters, Vol. 9 (1962), pp. 366-368.

(6) Goldman, L., Hornby, P., Meyer, R., Goldman, B., "Impact of the Laser on Dental Caries", Nature, Vol. 203 (1964), pp. 
417-423.

(7) Stern, R.H. and Sognnaes, R.F., “Laser beam effect on dental hard tissues”, Journal of Dental Research, Vol. 43 (1964), pp. 873.

（8）森岡俊夫，鈴木和雄, “レーザーによるう蝕予防(上)”，歯界展望, Vol. 62, No. 3 (1983), pp. 529-537.

(9) 山口博康, 小林一行, 佐藤恭道, 長田玲子, 菊池康次郎, 櫻庭栄一, 野村典生, 新井高, 中村次郎, “Nd: YAG $レ$ ーザーの表面麻酔効果”，日本レーザー歯学会誌，Vol. 9 (1998), pp. 9-12.

(10) Visuri, S.R., Walsh Jr, J.T., and Wigdor, H.A., "Erbium laser ablation of dental hard tissue: Effect of water cooling", Lasers in Surgery and Medicine, Vol. 18, No. 3 (1996), pp. 294-300.

(11) Mir, .M, Meister, J., Franzen, R., Sabounchi, S.S., Lampert, F. and Gutknecht, N., "Influence of water-layer thickness on Er:YAG laser ablation of enamel of bovine anterior teeth", Lasers in Medical Science, Vol. 23, No. 4 (2008), pp. 451-457.

(12) Armengol, V., Jean, A. and Marion, D., “Temperature Rise during Er:YAG and Nd:YAG Laser Ablation of Dentin”, Journal of Endodontics, Vol. 26, No. 3 (2000), pp. 138-141.

(13) Kumazaki, M. and Toyoda, K., "Removal of Hard Dental Tissue (Cavity Preparation) with the Er:YAG Laser", Journal of Japanese Society for Laser Dentistry, Vol. 6 (1995), pp. 16-24.

(14) 粟津邦男, 赤外レーザー医工学 (2008), pp. 103, 大阪大学出版会.

(15) Meister, J., Franzen, R., Forner, K. and Grebe, H., "Influence of the water content in dental enamel and dentin on ablation with erbium YAG and erbium YSGG lasers", Journal of Biomedical Optics, Vol. 11, No. 3 (2006), No, 034030.

(16) Kang, H.W. and Welch, A.J., "Effect of liquid thickness on laser ablation efficiency", Journal of Applied Physics, Vol. 101, No. 8 (2007), Art No. 083101.

（17）瀧澤雅一，天谷哲也，春山親弘，亀山敦史，高瀬安晶，平井義人，熊崎護，“Er:YAG レーザ照射時の注水量が象牙 質切削に及ぼす影響”，日本レーザー歯学会誌，Vol. 12 (2001), pp. 84-91.

(18) Colucci, V., Do Amaral, F.L.B., Pécora, J.D., Palma-Dibb, R.G. and Milori Corona, S.A., "Water flow on erbium:yttrium-aluminum-garnet laser irradiation: Effects on dental tissues", Lasers in Medical Science, Vol. 24, No. 5 (2009), pp. 811-818.

(19) Elijah, K.A., "Principles of Laser Materials Processing” (2009), pp.14-17, John Wiley \& Sons, Inc.

(20) Duck, F.A., "Physical properties of tissue" (1990), pp. 61, Academic Press.

(21) Papatsoris, A.G., Varkarakis, I., Dellis, A., Deliveliotis, C., "Bladder lithiasis, From open surgery to lithotripsy”, Urological Research, Vol. 34, No. 3 (2006), pp. 163-167.

(22) Furumoto, T., Ueda, T., Kasai, A. and Hosokawa, A., "Surface Temperature during Cavity Preparation on Human Tooth by Er:YAG Laser Irradiation”, CIRP Annals - Manufacturing Technology, Vol. 60, No. 1 (2011), pp. 555-558. 